\title{
Juggling with Indianness in the Gestation of Translation with Special Reference to the English Translation of a Hindi Story
}

\author{
Priya.K \\ Sree Kerala Verma College, \\ Thrissur, University Of Calicut, Kerala \\ E-mail: priyakprasad76@gmail.com
}

\author{
Doi:10.7575/aiac.alls.v.5n.4p.107 \\ URL: http://dx.doi.org/10.7575/aiac.alls.v.5n.4p.107
}

Received: 03/06/2014

Accepted: 15/07/2014

\begin{abstract}
This paper is an attempt to look closely at the process of translating dramas with special reference to the Hindi story Aadmi ka Baccha (The Child of a Man) by Yashpal in India and the role and significance of prose transcreations in today's changing global scenario.
\end{abstract}

Keywords: Translation, prose, India, transmigration, post coloniality

\section{Introduction}

Translation has assumed the form of a genre which binds the whole world in a dialogue. Translation has enabled the speakers of one language to free discourse with the speakers of any other language spoken in any part of the world. This has created an atmosphere of goodwill in the world. Through translation we become acquainted with the literature, culture, thought and problems of the speaker of a language different from our own. Translation thus establishes unity in diversity.

The process of translation is both complex and synthetic because the translator is bound by content of language as well as style.

Translation requires three essential qualities such as: 1. Accuracy .2. Clarity. 3. Flexibility.

It trains the learner to search flexibility for the most appropriate words (accuracy) to convey what is meant. (Clarity).

Translation does not consist in mere reproduction of ideas from one language in to another but must have a natural flow like the original. Plato feels that the translator must go through the same pangs of creation as the original artist. A translation should affect in the same way as the original may be supported to have affected first hearers. The translators intelligence and his linguistics competence enhance the quality of translation and raise it to the level of a work of a creative art. The translator should be a person endowed with keen sensibility because the quality of the translation and the form of its language demand of it. Dr. Kamalerhutar Bhatt speaks of three criterion for a translator. They are (i) knowledge of the source language. (ii) Knowledge of the target language, and (iii) knowledge of the subject. A good translation must be as readable as the original.

\section{Prose Translation}

It is usually considered that the translation of a prose text is not so difficult when compared to that of a poem. Many do argue that the structure of a novel or any prose work is simple and so it lands itself to translation easily, not posing much difficulty to the translator. But, in fact, translation of a prose work also requires careful attention and the work must be started only after a careful analysis is made from various angles. First the work should be fixed in its cultural background or else we may go wrong in the process because a literary work loses much meaning when it is seen in isolation.

Eugene Nida lays stress on a few important points to be observed before actually starting the translations process.

1. Lexico grammatical features of the immediate unit.

The Translator who chooses a particular unit like a long sentence or a short paragraph should decompose it in to its simplest forms and study their inter relationship. Proverbs, epigrams and figures of speech are all factors that determine meaning.

\section{Discourse context.}

The immediate unit that the translator is going to work with forms an integral part of the total discourse. So the particular unit must be analyzed in terms of the total discourse.

3. Communication context.

Circumstances involved in the original communication i.e matters like time, place, author, audience and recorded response add to the meaning of a message and very much influence it. 
4. Cultural context of the source language.

The larger cultural context is of great importance in understanding the meaning of message, for words have meanings only in terms of the total cultural settings and a discourse must be related to the wider sphere of human action and thought.

\section{Cultural context of the receptor language.}

This is also very important in translation, especially in the case of messages which have already been communicated in receptor culture.

The words that commonly pose difficulties for literary translators can be roughly divided into five groups. Words, which relate to:

a) Ecology b) Material culture c) Social culture

d) Description of non verbal communication e) Translation of proper nouns .

Hilaire Belloc laid down six general rules for the translator of prose texts. He advices the translator to consider the prose text as structured whole and also tells him to keep in mind the stylistic and syntactical exigencies of the TL. It is the middle part that he suggests; the translator has a moral responsibility to the SL text but at the same time he has the right to alter the text in such a way as to provide the TL reader with a text that conforms to TL stylistic and idiomatic norms.

In the multilingual, multi-cultural Indian literary context, translation has a definite role to play. The variety and diversity of the increasing body of significant writings in the Indian languages have necessitated closer look at the issues of translation if these works are to be recognized as being part of the body of world literature. The contemporary theory of literature in Hindi and other Indian languages presents a synthesis of the western and Indian ideas. The western linguistic models of Catford, Nida, Jacobson etc have influenced many writers in Hindi like Bholanath Tiwari, Rabindranath Shrivastava, Suresh Kumar, Bhatia Kailaschandra and others. The psycho-spiritual theories of Sri. Aurbindo have made deep impact on many modern Indian writers and translators. Dhvani or the theory of suggestive meaning and 'Auchitya' (appropriateness) are being applied as yardsticks of translation.

It is high time we recognized translation as a practical necessity especially in our country where communication take place through multiple languages. Building up a body of translated works wherein there is a constant flow of cultural interaction can contribute to the nourishing and strengthening of nationalistic ideas and also help in building up a broad based national literature.

\section{3. (Aadmi Ka Baccha) The Child Of A Man [YASHPAL]}

Dolly remains in her convent school till afternoon. After that she spends her time with her Aaya ${ }^{1}$ 'Bindi'. Mama (mother) awaits for Sahib for lunch in the afternoon. Sahib is always in a hurry. He arrives at sharp 1:07 p.m, washes his hands and face in the bathroom and by that time lunch is kept ready on the dining table. After finishing his food in half-an-hour Sahib goes back in his car smoking a cigarette. At the time of lunch, Dolly doesn't enter into the room and she eats separately.

Sahib comes back from the mill at 5.30 p.m. in the evening and is quite relaxed. At that time he definitely remembers Dolly. He talks to her for five to seven minutes and spends a long time talking to mama while having his cup of tea. If mama has to go somewhere in the afternoon, she returns home sharp at 5 O'clock and sends back the car to the mill for Sahib to come back home. She calls Dolly and makes her ready for Sahib's inspection. She makes Bindi wash Dolly's hands and face and comb her shining jet black hair in her presence. After Dolly's return from school, she removes her black and white frock, her school uniform and also the ordinary

frock which is worn in the afternoon and she is made to wear a new beautiful

frock. Her hair is tied with a ribbon. Mama even checks the polish on her sandals.

Bugga Sahib is the Chief Engineer of the mill. He had completed his higher education from abroad. He earns Twelve Hundred rupees per month. He is contended with his life but at the same time he is not indifferent to his duties and responsibilities. He has only one daughter - Dolly. Dolly is five years old. After her, no other child was born to them. Sahib and Mama are fully satisfied in fulfilling their duties towards their only child. Sahib holds very high ideals regarding his responsibilities of bringing up his child. He has considered Dolly both as his daughter and son and is happy about it. She shall obtain University education. After that it'll be necessary for her to go to England to complete her education and that's quite certain. To what extent can parents fulfill their responsibility of giving proper education to their children? Sahib says - "What is the use of giving birth to so many children like insects?" Mama Mrs. Bugga gives assent telling, "What else !"

"Dolly ! Dolly !! Dolly !!!” - Mama had called her thrice. Fourth time she called Aaya. When she didn't get any reply she went to the verandah angrily grinding her teeth. Now she too had to change her dress. She saw Aaya bringing Dolly from the backyard of their bungalow where the quarters of the dobi ${ }^{2}$ and gardener's are situated. Mama saw it and she stood startled. She understood - Dolly might have certainly gone to the gardener's house. Two - three days ago the gardener's wife had given birth to a child. She had insisted many a time to take the child in her arms. Mama was frightened as she had gone to the gardener's shack. Last week the dhobi's son had ringworms on his skin. 
When the girl goes out she mingles with the uncouth children and picks up and eats mulberry fruits lying under the tree. She was afraid that Dolly's habits would get spoilt by mingling with those children. Aaya was afraid that she would have to shoulder the responsibility for Dolly's faults. To show her helplessness at her daughter's uncontrolled behavior, she was walking one step forward clutching her arm as if an impatient goat was caught hold of its ears and taken home forcibly to graze the leaves in freedom.

Before Mama could say something, Aaya started to explain in a loud voice - "I had just gone inside after polishing her sandal. She said that she wanted to go to the bathroom. By the time I came out of the house she had reached the gardener's house. She never listens to my words. On the contrary when I try to make her understand, she beats me..."

In spite of this explanation, Aaya had to suffer scolding.

"This is very silly!", Mama severely scolded Dolly in English. Though Dolly couldn't understand the meaning of all the words spoken by mama, she realized her mistake and her Mama's anxiety over the matter.

Dolly's hands were washed with soap at once and her dress was changed. It was now 4.20 p.m. Therefore Aaya was helping her wear socks and sandals very swiftly. Mama herself was combing her hair and tying her plaited hair with ribbons. While she was caressing her daughter's eyelids with affection, she found something on her neck quite unexpectedly - "a louse!" It was a disaster! Certainly it was the result of the association with the gardener and the dhobi. Aaya was scolded again and she was given warning that if Dolly was found playing with dirty, astray children again, she would be dismissed.

On seeing this sad plight of her daughter, her heart melted. Giving up English, she started making her daughter understand in an affectionate way - "Dolly is our sweet and loving child, very beautiful and our darling daughter. We dress her up in beautiful clothes. Dolly, you go to school with the children of English people, Don't you? And that too sitting in a bus? You shouldn't play with such dirty children?"

Dolly stamping her feet on the carpet said stubbornly - "Mama, give me the gardener's baby. I will love him."

"Ugh! Shame!" Mama made her understand, "He is such a dirty child! By playing with such dirty children, we'll also become dirty. You'll get lice on your head by playing with them. They are so ugly - black - black! Dhath! Is our Dolly black? Aaya, take Dolly to the Manager Sahib's house to play. There she will play with Raman and Jyothi. Take her to the company's park in the evening."

Dolly put her arms around her mother's neck and assured her that she would never again play with such dirty and black children of the inferior people. That evening, while having tea, Bugga Sahib and Mrs., Bugga were having a discussion on why children like to play with small babies of inferior people ... It is very difficult to bring up even a single child. God only knows how people manage to bring up so many children. Look at the gardener! That wretched fellow had already three children and now he has one more.

Bugga Sahib had a dog of a peculiar breed. It was light almond in colour and had soft and silk hair on its neck and tail and a broad chest. The elbows of the arms were pushed out, the belly was attached o the back and the mouth appeared to be situated behind due to some wound. Visitors got attracted towards it and couldn't help having a look at it. This was its usefulness and particular feature. The cost of this thing of fancy was rupees two hundred and fifty.

The dog gave birth to puppies. For Dolly it was a big occasion for celebration. She never liked to move away form the puppies. There were many people who wanted to possess the puppies whose eyes were narrow like that of rats. But to whom should it be given and who should be refused? If this breed is distributed in such a manner wouldn't it lose its value? Two hundred and fifty rupees, the cost of the dog was not even sufficient to buy milk for it.

Sahib's order was that if the dog gave birth to puppies they should be killed by the sweeper by immersing them in hot water. They wanted to do the same this time also, but they were worried about Dolly. Finally, when Dolly had gone to school, the servant asked the sweeper to do the job.

After returning from school, Dolly started searching for the puppies. Aaya said -"The puppies have been sent to the Manager Sahib's house to show them to Raman . They will come back in the evening." Mama said, "Baby the puppies are sleeping. You can play with them after they wake up." But Dolly continued to search for the puppies. At last she came to know through the sweeper that they were killed by dipping them in hot water.

Dolly was weeping very badly. Aaya took her to the company's park to make her quiet. Dolly was asking repeatedly "Aaya, why were the puppies killed by immersing them in hot water?"

Aaya explained to her - "How could Dany (the dog) feed so many young ones. They were squeaking out of hunger. So they were killed. Dany and Dolly mourned for two days for Dany's puppies and then like other people they too forgot about them. At any time of the day - whether it was midnight, afternoon, morning or evening, the crying 'kein - kein' sound of the gardener's baby could be heard. Mrs. Bugga was very displeased with the matter. She used to say angrily -"Who knows how big is the hole in its throat?"

She used to get even more angry on hearing the kein-kein sound of the baby when Dolly kept on asking - "Mama, why is the gardner's baby crying?"

Bindi ( Aya) sitting beside them, spoke - "What can he do other than crying ? His mother doesn't have any milk." Bindi and Mama did not notice that Dolly was listening to them. Dolly replied suddenly-"Mama, ask the sweeper to immerse the gardener's baby in hot water, then he won't cry." 
On hearing this, Bindi started to laugh and pressed the end of her sari to her lips. Mama was startled. Dolly was looking at them with her simple and innocent eyes expecting their approval.

"This is very silly Dolly! Does any one say such things regarding a human child?" Mama corrected her thoughtfully. On seeing this situation, Aaya took Dolly for a walk.

On the third day in the evening, Dolly was returning from the Manager Sahib's house after playing with Raman and Jyothi. She saw the gardener standing at the door of her bungalow carrying his new baby, wrapped in plain cloth, and going outside, his wife following him crying.

Aaya caught hold of Dolly's hand and moved her away from their shadow. Dolly asked her - "What is this, Aaya! What is the gardner carrying?"

"The youngest child of the gardener died", Aaya replied softly and took her inside the bungalow, holding her hands.

She looked fixedly at Aaya with her wet, blue eyes and asked -“Aaya the gardener's baby was immersed in hot water?"

"Chi, Dolly! You shouldn't say such things", Aaya rebuked her," Does anybody kill a human child in such a way ?"But Dolly's astonishment was not calmed. She turned around to look at the gardener who was quite far away from them and asked again-"Then how does a human child die?"

To divert her attention, she dragged her inside the bungalow and replied - "He died .He died out of hunger. Get in. Mama is calling you." Dolly did not keep quiet. She asked again-"Shall we also die of hunger?"

"Keep quiet, Dolly,"Aaya snapped at her," If you say such things, I'll complain to Mama."

But her mother's heart was moved on seeing the innocence on her daughter's face. Aaya spoke stroking her curly hair-“"Oh, my Miss Sahib, Are you such a child!........ Children of the wretched people are the ones who die out of hunger!"

Saying this her throat went dry. She remembered her Lallu - - Two years back - - only after that she had started to come to work at Sahib'shouse.

\section{Conclusion}

Different scholars have described translation as art, craft and science. Translation is all these and much more. It is a process of analysis, interpretation and creation. It is an act of adjustment and compromising exercise.

During translation it is difficult or rather impossible to find TL equivalents which have all the meanings or which carry all the implication of a SL word. While translating such words, therefore, loss of some kind is inevitable. "To translate is to change into another language, retaining as much sense as one can", says A H Smith. But retaining the sense alone is not enough. We have to maintain the semantic compatibility along with grammaticality. A translator should have a perfect knowledge of both the source and target language and the words should "Obey his call". Above all, he should have the "feel" of the language. He should be able to create an equivalent effect on the Target Language readers as that have been produced in the Source Language readers by the original text. All these factors have to be borne in mind when approaching the translation of any text.

There are various kinds of situations where the translators face the problem of untranslatability during the translation process. Literal translation should be avoided at all cost because it fails to carry the transposition of culture. Language is largely culture oriented and therefore, translators face the problem of translating certain culture based words into another language with a different culture as the impact of them gets lost in the process of translation. For example the simple words 'you' in English has three corresponding words in most of the Indian language including Hindi. In Hindi it means 'Tu,' 'Tum,' 'Aap' depending up on the relationship with the person to whom the speaker addresses. Colloquial expressions, culture-words, slangs, proverbs are difficult to translate for there is no one-to-one correspondence between one culture and another or one language and another. Certain food items of India like 'Halva', 'Puri', 'Paratha', etc and words of common use in everyday conversation based on culture cannot be translated accurately into a foreign tongue. Homonyms of Indian language create problems to the translators. Polysemy or oligosemy like lexical gaps, also obstruct successful translatability. Moreover, the translator should be able to differentiate between the denotative, connotative and idiomatic meanings, or else translation of these words will be still more problematic.

The difference in the word order of English, that is SVO, and that of most of the Indian languages, that is SOV, and the usage of simple tense in English and present progressive tense in Indian languages pose difficulties to the translator. The problematic jokes are very difficult to translate. Unless one knows the exact origin of the joke it will not be possible for him to translate it into another language. Translations of metaphors pose a special kind of problem and the translator's burden is how to translate metaphors without affecting the SL discourse. Words that relate to ecology, material culture, social culture, description of non verbal communication and proper nouns pose difficulties to the literary translators. Idiolects, dialects, registers, style of language may also be problematic during translation. Translating mythological names are also difficult.

In 'Aadmi Ka Baccha', Aaya Bindi speaks a local dialect which cannot be satisfactorily incorporated in the target text, for example, phrases and expressions like 'Tayi beetar gayen', 'Hum ko to kuch ginti hi nahin'. The expression 'bairi ki aankh mein rayi non' had to be omitted by the translator due to the lack of corresponding expression in the Target Language culture. Another instance of untranslatability occurred when Dolly, the central character of the story, wants to possess the gardener's baby. But mother makes Dolly understand that they are dirty children. To retain the mood of the 
situation the translator has transliterated the expressions 'Dhath', 'Chi', of the source text. Such expressions do not exist in the target language. Yet if it is omitted or altered there will be inadequacy in expressing Mama's disgust over the matter. Moreover, the author had used certain English words to show that the protagonist Dolly's family belongs to an educated elite class. For example, 'lunch', 'mama', 'notice', 'this is very silly'. They have just been transliterated as English is the target language.

Even though the translator faced few difficulties in translating the source text in order to express the sense and feeling of the authors, she believes she could successfully reflect the authors' intentions. The translator's task is more difficult than a creative writer's because he has to make a tight rope walking between two languages - Source Language and Target Language Ironically, it is the problems that make the art of translation challenging and at the same time fascinating.

\section{References}

Rajendra M. (ed). (1998). Katha Kunj. Lok Bharati Publications: Arop Krishna.

Bassnett Mc Guire, S. (1980). Translation Studies. London: Methuen.

Catford ,J.C. (1965). A Linguistic Theory of translation. London: Oxford University Press.

Nida, Eugene, A., and Charles.R.T. (1969). The Theory and Practice of Translation. Leiden: E.J.Brill.

K.Ray, M. (2002). Studies in Translation. New Delhi: Atlantic Publishers. 